\title{
Monitoring and Evaluation Strategies for Quality Control Assurance in Tertiary Educational Institutions in Ebonyi State
}

\author{
Paul Nwakpa \\ Department of Educational Foundations \\ Faculty of Education. Ebonyi State University \\ Abakaliki, Nigeria \\ Email: bropaulnwaoo [AT] gmail.com
}

\begin{abstract}
This paper examined monitoring and evaluation strategies for quality control assurance in tertiary educational institutions in Ebonyi State. The concepts of monitoring, evaluation, quality control and quality assurance were discussed. Various problems facing monitoring and evaluation as strategies for quality control and quality assurance in tertiary educational institutions in Ebonyi State were also dealt with. The paper examined monitoring and evaluative strategies for improved quality. The study adopted descriptive survey design. Total population of 270 respondents was used in the study. A questionnaire instrument was used to collect data for the study with 35 items. The instrument was validated by three experts in the department of Educational Foundations of Ebonyi State University. A reliability index of 0.88 was obtained using cronbach alpha formula. The study was guided by one research question and one null hypothesis. Mean scores were used to answer the research question and t-test was used to analyze the null hypothesis. The study revealed that the 35 suggested strategies were all accepted and the null hypothesis was upheld. The study recommended a total adoption of the 35 strategies by the school management.
\end{abstract}

\section{INTRODUCTION}

It is no longer a story that the quality of education in Nigeria had declined at all levels. It is quite unfortunate that the standard of university education is allowed to deteriorate to the level that some of the products cannot express themselves grammatically. This scenario actually calls for serious concern. The quality of tertiary education of any nation determines the quality of production of such nation. The quality of life of a people, the economic, social and political development of a people is dependent on the type of education received by the people. Education is the only available instrument for total reformation of a people.

No wonder the Federal Government of Nigeria (FGN) in (2004) declared education as instrument per excellence. Having known that education is an instrument per excellence in all spheres of life, while then do we joke with its quality in this $21^{\text {st }}$ century? We need to trace the causes of falling standard in education especially at the tertiary level where everything is supposed to be perfect, and where the hope of every person or nation lies.

First and foremost, what is quality? Quality according to Nwankwo (2007) is a set standard against which the outcomes are measured. Mutsaphah in Nwankwo (2007) saw quality as the success with which an institution provides educational environment which enables students to effectively achieve worthwhile learning goals including right academic standard.

Quality in education is a multidimensional concept which should embrace all functions and activities: teaching, and academic programmes, research and scholarship, staffing, students, buildings, facilities, equipment, services to the community and academic environment (UNESCO, 1998). Quality of an education system (primary, secondary and tertiary) means the extent to which their education system achieved its set goals. This implies that the products of the education system are able to solve the environmental and social needs of that nation. Thus, quality entails the standard of something when compared with other things.

Concern about quality is uppermost in educational discourse all over the world. This is quite understandable given the growing importance of trans-border education provisions in the wake of globalization and mystification of education. Generally, stakeholders, in education are anxious to see that educational institutions deliver what they should deliver and produce desirable outcomes.

Of course yes, the purpose of quality control in education, there must be organized supervision, evaluation, close monitoring of processes and products. The concern here is on improving the education programme the issue of quality and its control mechanism in all ramifications. In this connection, the question arises as to what goals are to be highlighted and how do we ensure high quality in the inputs and process in order to ensure high quality products. 
According to Coombs and Hallak in Nwakpa (2015), improvement in instruction and programmes means a broadening and continuity of educational opportunities and the chance for each individual to learn more in each time period, an educational content that is up to date, relevant and useful to each learner in his own particular society. This means that the educational system must be flexible and effective. Effectiveness here refers to system level criteria of Schein (1970) in which each System has a multiple functions and exists within an environment that provides unpredictable inputs, and its effectiveness being its adaptive capacity to survive, adapt, maintain itself and grow regardless of the particular function it fulfills.

Quality control is a whole area of research that needs to be seriously addressed by all stakeholders in education. Unless this is done, we shall continue in vicious circle of poor quality education. Doll (1978) was of the opinion that there must be evaluation data on which to determine whether to continue a programme, or to abandon it. But in Nigeria, there is dearth of reliable data for effective job to be done in terms of evaluation. But nevertheless monitoring could be used to check on quality.

Monitoring according to Nabris (2012) is an ongoing activity to track the progress being made by an entity or a phenomenon against a planned task. Abe (2012) said that monitoring is aimed at: improving efficiency and effectiveness; helping to keep work on track and allows management to know when things are going wrong, enabling organizations to find out if resources available are sufficient and well used accountably; and finding out if capacity available is sufficient and appropriate and then providing useful base for evaluation.

Evaluation is all about appraising or judging of performance of workers against a stated goals and objectives using any or various testing parameters. Stuffleabeam and Shinkfield (2007) described evaluation as the society's most fundamental discipline and went further to define it as a process for giving attention on such matters as reliability effectiveness, cost effectiveness, efficiency ease of use and probity and services, the need of the society by providing affirmation of work, value, improvement, accreditation and accountability. It is a periodic objective assessment of a planned project, programme or policy. In practical terms, evaluation is used to help in decision making in how to improve on group programmes.

According to Imas and Rist (2009) evaluation can be used to address such questions as what is taking place (descriptive question), normative question such as comparing what is taking place with what should be taking place for quality assurance, therefore evaluation will appraise the status of change brought about by the students and the institutions (a change in students' behavior). It will also expose students' needs and possibilities. Evaluation in quality assurance will aid institutions in planning and expanding the concept of worthwhile goals and objectives.

Monitoring and evaluation will provide the stakeholders in education with much desired extent to which the institutions are meeting the aims and objectives of their establishment. Monitoring and evaluation will build greater transparency and accountability in terms of use and available resources in assuring quality in the institution (Abe, 2012).

Monitoring, evaluation and quality assurance in tertiary educational institutions is carried out through external assessment by the school moderating bodies like National Universities Commissions (NUC), National Commission for Colleges of Education (NCCE) and others.

Internally, the school administrators plan, organize, direct, coordinate, evaluate and control the teaching-learning processes to ensure that they are properly done according to procedures, rules and policies stipulated by the school authority. Externally, the moderating bodies also pay visits to schools to ensure that things are done accordingly in terms of adequate provision and utilization of both human and material resources in schools as to achieve the stated goals and objectives of tertiary educational institution.

But despite all these activities to ensure quality in tertiary educational institutions in Ebonyi State, the problem of poor quality products persists and on that note the researcher wished to evolve strategies to be adopted to ensure that there is quality assurance in tertiary educational institutions in Ebonyi State and even beyond.

\section{STATEMENT OF THE PROBLEM}

It has been observed that the quality of tertiary education in Ebonyi State has dropped drastically in the sense that many of the products of tertiary institutions in Ebonyi State hardly express themselves in simple English language, some not employable because of inadequate possession of skills needed by employers of labour.

It has also been observed that teaching resources that are supposed to be used in teaching are inadequate in supply if not total lack of such resources. Further more, it is a fact that the academic staff that impact knowledge, skills ideas etc are not often exposed to such knowledge, skills etc through constant training and retraining.

The problem of quality control and assurance cannot be easily solved when the drivers of quality education (academic staff) are not adequately encouraged through proper motivation especially in terms of staff welfare. The problem of this study is then how to ensure high quality of education at the tertiary level of education. 


\section{SIGNIFICANCE OF THE STUDY}

The outcome of this study will be beneficial to the school management; the teachers, students and the government. The school management will benefit when the quality of education is improved in the sense that many students will be willing to enroll in their schools and the status of the schools will appreciate. The teachers will also benefit as more teaching resources will be made available to them, and these enhance their job performance. Students will also benefit as they will be taught properly and this will raise their academic standard.

\section{PURPOSE OF THE STUDY}

The main purpose of this study was to evolve innovative strategies that could be used to solve the problem of poor quality of tertiary education in Ebonyi State.

\section{Research Questions.}

One research question guided the study.

Research Question 1: What are the innovative strategies to be adopted to solve the problem of poor quality of tertiary education in Ebonyi State?

\section{Hypothesis.}

One null hypothesis guided the study.

HO1: There is no significant difference in the mean ratings of respondents from Ebonyi State University and Ebonyi State College of Education, Ikwo on the strategies to be adopted in order to solve the problem of poor quality of tertiary education in Ebonyi State.

\section{METHODOLOGY}

The study adopted descriptive survey design. The population of the study consisted of 1005 academic staff from Ebonyi State University (EBSU) and 65 academic staff from Ebonyi State college of Education (ESCE) totaling 1070 academic staff. $25 \%$ of the entire population, making 270 academic staff was used as the sample size.

Purposefully, all the academic staff of Ebonyi State College of Education (65) were used while 205 of Ebonyi State University were used in the study. The instrument for data collection was A-35 item modified Likert-scale questionnaire tagged, "Innovative Strategies for Improving the Quality of Tertiary Education in Ebonyi State Questionnaire” (TSIQTEESQ).

The instrument was made up of two sections A and B. Section A sought information on personal data of the respondent while section $B$ sought information on innovative strategies to be adopted. The instrument was constructed by the researcher using a modified Likert 4-Point scale of Strongly Agree (SA, 4-Points), Agree (A, 3 Points), Disagree (D, 2 Points) and Strongly Disagree (SD, 1 Point). A criterion mean of 2.50 was used to guide decisions. Thus, any item with a mean of 2.50 and above was accepted as a good strategy to be adopted, while any item with less than a mean of 2.50 was rejected, and thus was not regarded as a good strategy to be adopted.

The instrument was validated by three experts from the department of Science Education of Ebonyi State University, Abakaliki. The Reliability index of the instrument, 0.88 was obtained using Pearson product moment correlation coefficient.

With the help of eight research assistants, the instrument was administered on the respondents and was collected at the spot. The mean was used to answer the research question, while t-test was used to analyze the hypothesis at 0.05 level of significance. 


\section{RESULTS}

Research Question 1: What are the innovative strategies to be adopted to solve the problem of poor quality of tertiary education in Ebonyi State?

Table1: Mean scores of the respondents on innovative strategies to be adopted to solve the problem of poor quality of tertiary education in Ebonyi state.

\begin{tabular}{|c|c|c|c|c|c|}
\hline \multirow[t]{2}{*}{$\mathbf{S} / \mathbf{N}$} & \multirow[t]{2}{*}{ Innovative strategies } & \multicolumn{2}{|c|}{ EBSU N=205 } & \multicolumn{2}{|c|}{ ESCE N=67 } \\
\hline & & $\mathbf{x}$ & Decision & $\mathbf{x}$ & Decision \\
\hline 1. & Provision of adequate lecturers & 3.5 & & 3.1 & \\
\hline 2. & $\begin{array}{l}\text { Provision of adequate welfare package for } \\
\text { lectures }\end{array}$ & 3.8 & & 4.0 & \\
\hline 3. & $\begin{array}{l}\text { Provision of adequate staff development } \\
\text { programmes }\end{array}$ & 3.7 & & 3.8 & \\
\hline 4. & Provision of regular staff promotion. & 3.6 & & 4.0 & \\
\hline 5. & Regular payment of staff allowances. & 3.3 & & 3.6 & \\
\hline 6. & Provision of staff Retirement benefits & 3.8 & & 3.8 & \\
\hline 7. & $\begin{array}{l}\text { Academic staff to go through normal recruitment } \\
\text { process to avoid mediocrity. }\end{array}$ & 2.8 & & 3.0 & \\
\hline 8. & $\begin{array}{l}\text { To check on staff attendance } \\
\text { to lectures by a team }\end{array}$ & 2.6 & & 2.8 & \\
\hline 9. & $\begin{array}{l}\text { To check on how the staff delivers his/ her } \\
\text { lectures by a team. }\end{array}$ & 2.7 & & 2.5 & \\
\hline 10. & To check on how staff mark scripts by a team & 2.8 & & 2.6 & \\
\hline 11. & To moderate staff examination questions. & 3.3 & & 3.1 & \\
\hline 12. & To effectively invigilate all examinations. & 3.6 & & 3.4 & \\
\hline 13. & $\begin{array}{l}\text { To avoid Quota system in recruiting the students } \\
\text { but to use merit in admission only. }\end{array}$ & 3.8 & & 3.3 & \\
\hline 14. & $\begin{array}{l}\text { Identified very weak students should be withdrawn } \\
\text { from school. }\end{array}$ & 3.7 & & 2.6 & \\
\hline 15. & $\begin{array}{l}\text { The } 75 \% \text { attendance on the students to sit for } \\
\text { examination should be enforced. }\end{array}$ & 3.8 & & 3.4 & \\
\hline 16. & $\begin{array}{l}\text { Examination malpractice should be given zero } \\
\text { tolerance. }\end{array}$ & 3.6 & & 3.8 & \\
\hline 17. & $\begin{array}{l}\text { Lecturers should be made to submit the question } \\
\text { papers and their marking scheme to their } \\
\text { departments and thus their scripts to be marked by } \\
\text { another lecturer. }\end{array}$ & 3.4 & & 2.6 & \\
\hline 18. & The work load on lecturers should be appropriate. & 3.6 & & 3.8 & \\
\hline 19. & $\begin{array}{l}\text { Time for everything must be judiciously used by } \\
\text { all concerned. }\end{array}$ & 2.7 & & 3.0 & \\
\hline 20. & $\begin{array}{l}\text { The learning environment should be made } \\
\text { conducive. }\end{array}$ & 3.6 & & 3.7 & \\
\hline 21. & $\begin{array}{l}\text { All means to avoid industrial actions must be } \\
\text { provided. }\end{array}$ & 3.3 & & 3.6 & \\
\hline 22. & Lecturers' offices should be made conducive. & 3.4 & & 2.7 & \\
\hline 23. & $\begin{array}{l}\text { Class rooms/ lecture halls must be made } \\
\text { conducive. }\end{array}$ & 3.6 & & 3.0 & \\
\hline 24. & Libraries must be made conducive and adequate. & 3.0 & & 3.5 & \\
\hline 25. & $\begin{array}{l}\text { Laboratories must be made to meet the needed } \\
\text { requirements. }\end{array}$ & 3.7 & & 3.6 & \\
\hline 26. & $\begin{array}{l}\text { Academic Programmes must be updated } \\
\text { regularly. }\end{array}$ & 3.4 & & 3.0 & \\
\hline 27. & Learning facilities must be made available. & 3.2 & & 3.7 & \\
\hline 28. & Provision of students' hostels is necessary. & 2.6 & & 3.0 & \\
\hline
\end{tabular}


29. Teaching practice, practicums, industrial training

(IT) etc must be given adequately attention.

30. Large classes must be avoided.

31. Students must be encouraged to be buying their recommended text books.

32. Students' note books should be checked and marked by the concerned lecturers.

33. Enough continuous assessment must be given to students so as to keep them ever busy.

34. Teachers must be disciplined and morally upright 2.6 and to inculcate the same in students.

35. Students should not be examined on courses they have not been taught.

Grand Mean ( $\mathbf{x}$ )
3.0

3.4

Data in table 1 show the responses of the respondents to the questionnaire items as good strategies to be adopted as good solutions to the identified problem that is, poor or low quality of tertiary education in Ebonyi State.

The table 1 had 35 suggested strategies which the respondents were to either accept or reject as strategies to be adopted. It is interesting to note that all the 35 items scored above mean of 2.5 by both respondents from Ebonyi State University, Abakaliki and Ebonyi State College of Education, Ikwo. So, it is the opinion of all the respondents that the 35 suggested strategies by the researcher should be adopted in order to solve the problem of poor or low quality of tertiary education in Ebonyi State.

\section{Hypothesis:}

HO1: There is no significant difference in the mean ratings of respondents from Ebonyi State University Abakaliki and respondents from Ebonyi State College of Education, Ikwo on the strategies to be adopted to solve the problem of poor quality of tertiary education in Ebonyi State.

Table 2: t-test analysis of difference between the mean scores of Ebonyi State University Abakaliki and respondents from Ebonyi State College of Education, Ikwo academic staff on strategies to be adopted in order to solve the problem of poor tertiary education in Ebonyi State.

\begin{tabular}{llllllll}
\hline Institution & $\mathbf{N}$ & $\mathbf{X}$ & SD & DF & t-cal & t-crit & Result \\
\hline EBSU & 205 & 3.3 & 0.17 & 268 & 1.08 & 1.96 & Accept \\
ESCE & 65 & 3.3 & 0.17 & & & & \\
\hline
\end{tabular}

\section{$\mathrm{N}_{1}(\mathrm{EBSU})=205, \mathrm{~N}_{2}(\mathrm{ESCE})=65 \mathrm{df}=268, \mathrm{t}-\mathrm{crit}=1.96$}

The obtained t-calculated was 1.08. This value was tested for significance by comparing with the critical t-value of 1.96 at 0.05 alpha level and degree of freedom. The obtained t-calculated of 1.08 was less than the critical t-value of 1.96. Hence, the null hypothesis was retained. It implies that there is no significant difference in the responses of respondents from Ebonyi State University Abakaliki and respondents from Ebonyi State College of Education, Ikwo regarding the suggested strategic to be adopted to solve the problem of poor quality of tertiary education in Ebonyi State.

\section{DISCUSSION OF FINDINGS}

Quality of education in every level or system of education depends largely on availability of educational inputs, environmental atmosphere, effective management of both human and material resources. The level of motivation given to the quality drivers (teachers) and how students are also encouraged to take their studies seriously. When teachers and students are positively motivated, there will be quality assurance in education.

Chukwu (2008) contented that learning resources includes well spaced classroom enough buildings well stocked libraries and laboratories. He maintained that such resources go a long way in intimating both teachers and students; thereby enhancing quality of education.

Uche (2011) believed that a well motivated worker in terms of remuneration gives his best in accomplishing his task. This agrees with some of the strategies in this study, such as (welfare, regular payment of salaries, retirement benefits).

The finding of Ude (2010) revealed that timely promotion of workers and provision of development programmes to workers serves as impetus to high quality of output and also increased output. This agrees with the strategy or strategies 
on staff promotion and development programmes. Though the strategies to be suggested that when employed will arrest the problem of poor or low quality of tertiary education in Ebonyi are still remaining, but the adoption of the suggested and accepted 35 strategies in this study by both the researcher and the respondents will go a long way to see that the problem of this study is solved.

\section{CONCLUSION}

Quality education especially at the tertiary level ensures quality outputs in all the sectors of the economy. The adoption of the suggested strategies and okayed by the respondents by the school management will kick out completely the problem of poor or low quality of tertiary education in Ebonyi State and beyond.

\section{RECOMMENDATIONS}

Based on the findings of this study, the following recommendations were made:

1. The stakeholders in tertiary education in Ebonyi State should adopt the 35 revealed strategies for improving the quality of tertiary education in Ebonyi State for the good of the school, the government and the national economy.

2. The Ebonyi State government should as a matter of importance allocate enough funds to tertiary education so as to reap the benefits of quality tertiary education.

3. Parents on their own should ensure that they provide the necessary school materials for these children.

4. Students on their own should see that they take their studies seriously.

\section{REFERENCES}

- Abe J.J (2012) "Quality Education” Owerri: Onyeoma Publication.

- Chukwu, L.C (2008) teacher motivation is Enugu State; implications for quality assurance in universal basic education (UBE) programme. Nigeria journal of curriculum studies. Special education PP1-7.

- Imas, L.M \& Rist R (2009). The road to result: designing and conducting effective development evaluation. The Word Bank, Washington DC.

- Nabia, K. (2012) civil society empowerment through training and skilled development PASSIA.

- Nwakpa, P. (2015) Monitoring and evaluation as Indians of quality control assurance in secondary education in Nigeria. International journal of research development A (1) $243-249$.

- Nwankwo, S.N (2007) Introduction to Educational Supervision in Nigeria Onitsha: Etikokwu Publications.

- Uche, N.G (2011) "Motivation" Abakaliki: Omenga printing press.

- Ude J.O (2010) worker in centers; panacea to low productivity in organization. Seminar paper presented to dept of Educational Foundations EBSU.

- UNESCO (1998) Higher education in the $21^{\text {st }}$ century: vision and mission world declaration on higher education for priority actions for change and development in higher education UNESCO Paris. 